\title{
MAPPING LITHOLOGY AND HYDROTHERMAL ALTERATION IN GEOTHERMAL SYSTEMS USING PORTABLE X-RAY FLUORESCENCE (pXRF): A CASE STUDY FROM THE TAUHARA GEOTHERMAL SYSTEM, TAUPO VOLCANIC ZONE
}

\author{
Kate Mauriohooho ${ }^{1}$, Shaun L.L. Barker ${ }^{1 *}$ and Andrew Rae ${ }^{2}$ \\ ${ }^{1}$ School of Science, The University of Waikato, Private Bag 3105 \\ Hamilton 3240, New Zealand \\ ${ }^{2}$ GNS Science, Wairakei Research Centre, Private Bag 2000, Taupo 3352, New Zealand \\ *sbarker@waikato.ac.nz \\ km179@students.waikato.ac.nz
}

Keywords: $p X R F$, chemostratigraphy, Tauhara, geochemistry, geothermal, element

\begin{abstract}
Portable $\mathrm{x}$-ray fluorescence (pXRF) analyzers are widely used in environmental studies and mineral exploration. pXRF analyzers can rapidly and inexpensively provide chemical concentrations on a variety of elements, often with detection limits of $\sim 1-5 \mathrm{ppm}$. We compared portable XRF results from untreated geothermal drill cuttings with traditional laboratory XRF analyses carried out on powders prepared from the same samples. It is demonstrated that the portable XRF results are accurate for many elements, particularly for those with atomic numbers greater than 17. 304 cutting samples from three drillholes in the Tauhara geothermal field were subsequently analyzed by pXRF. Downhole elemental concentrations plotted with respect to lithological units defined on well logs reveal that significant variations in elemental concentrations occur downhole, some of which correlate with logged lithology boundaries. Other chemical variations appear to define previously unrecognized subunits, as well as areas of hydrothermal alteration. We suggest that pXRF should become a routine part of the characterization of geothermal cuttings during geothermal exploration and well drilling, as the chemical results are accurate, and can be obtained rapidly and at low cost. The results can be used to define lithological boundaries and potentially correlate between drillholes, therefore improving geologic, stratigraphic and hydrothermal alteration models of the geothermal field.
\end{abstract}

\section{INTRODUCTION}

Established practices that characterize the geology of geothermal fields involve primary (host rock) and secondary (alteration) mineral identification using visual description of drill cuttings and drillcore, optical microscopy and x-ray diffraction (XRD). However, the downhole lithogeochemical variations (i.e., whole rock chemistry) of the cuttings and/or core are typically not assessed due to time and cost considerations (Libbey \& William-Jones, 2015), despite the widespread application of lithogeochemistry to the study and exploration of hydrothermal ore deposits which are thought to represent the fossil equivalents of active geothermal systems (Hedenquist, 1991; Hedenquist \& Lowenstern, 1994; Simmons \& Browne, 2000; Simmons et al., 2005). Epithermal deposits commonly have zoned alteration halos where geochemical vectors and mineral variations can identify where areas of high fluid flux previously existed. Chemical signatures include variations in $\mathrm{K} / \mathrm{Al}, \mathrm{Na} / \mathrm{Al}$ and $\mathrm{Ca} / \mathrm{Al}$ ratios (reflecting alteration of feldspars and precipitation of adularia), as well as variations in concentrations of "pathfinder" elements (Warren et al., 2007). Such variations can therefore be used as vectors towards precious metal mineralization, representing former hydrothermal fluid flow pathways. 
Advances in portable $\mathrm{x}$-ray fluorescence ( $\mathrm{pXRF}$ ) technology mean that the chemical composition of samples collected during the drilling of geothermal wells can now be rapidly and inexpensively determined. The pXRF is a handheld device that contains an x-ray source and detector and is used to chemically characterize a sample via $x$-ray fluorescence. The x-ray source generates a beam of $\mathrm{x}$-rays that excites the atoms in the sample resulting in inner shell electrons being displaced. Outer shell electrons move into the space vacated by the inner electrons triggering fluorescence. Fluorescence is the electromagnetic radiation or Brehmstrahlung x-rays that are emitted as a result of the difference in energy between the two electrons. The number and energy of x-rays are detected via energy dispersive spectroscopy (EDS; Shindo \& Oikawa, 2002) and is characterized as a spectrum containing numerous peaks. Because each element has its own atomic structure, the emission spectrum of elements is unique (although peak overlaps can occur), which means that both the presence and concentration of various elements can be determined (with appropriate treatment of peak overlaps).

The output data varies between portable XRF makes and models, so for consistency the same instrument should be used throughout a sampling project (Goodale et al., 2012; Brand \& Brand, 2014). Measured concentrations are affected by various factors, including sampling preparation and grain size, nugget effects (e.g. a chunk of a particular mineral with elevated concentrations of a particular element or elements, such as a piece of arsenopyrite yielding an anomalous As concentration), surface irregularities, sample thickness, weathering effects and the depth of x-ray penetration from the emitted x-rays, which is usually submillimetre but dependent on an element's atomic weight and the sample matrix (Potts et al., 1995, 2006; Jones et al., 2005; Brand \& Brand, 2014; Gazley \& Fisher, 2014). For best results, homogenization of a sample is recommended by grinding into a finer grain size or pulverized into a powder.

In this contribution, we have used a portable XRF instrument to analyze the concentrations of elements in 304 samples from three geothermal wells in the Tauhara geothermal field located in the Taupo Volcanic Zone, New Zealand. The portable XRF results from 45 samples were compared to lab-based XRF results determined on cuttings that were crushed and prepared as pressed pellets and lithium borate fused beads. By comparing results from both instruments, we demonstrate that pXRF analysis directly from drill cuttings can produce accurate trace element compositions without the need for further sample preparation. The geochemical variations determined down three drill holes from the Tauhara geothermal field are interpreted to reflect both variations in host lithology, as well as variable hydrothermal alteration. Our results suggest that pXRF technology should be utilized as a routine part of geothermal exploration, as the results are accurate, inexpensive and allow lithological units to be easily differentiated on the basis of geochemistry. Units with distinctive geochemical features can then be correlated between drill holes resulting in improved geological models.

\section{GEOLOGICAL SETTING}

\subsection{Location}

The Tauhara geothermal field lies northeast of Lake Taupo within the Taupo Volcanic Zone in the central North Island, New Zealand (inset, Fig. 1). The field has a total surface area of $50 \mathrm{~km}^{2}$ (Rosenberg et al., 2010) and is bordered by the Waikato River on the western side and Mt Tauhara, an extinct dacite volcano, to the southeast (Steiner, 1977; Fig. 1). It is classed as a high enthalpy resource, with a natural energy output of $110 \mathrm{MWt}$ (megawatt thermal) (Bibby et al., 1995). The field occurs southeast of the neighbouring Wairakei geothermal field, and although both fields have separate up-flow zones, previous studies have documented a shallow hydrological connection between the two fields, with pressure drawdown at Tauhara linked to long-term fluid withdrawal for Wairakei steam production (Hunt \& Graham, 2009; Milloy \& Wei Lim, 2012). 
The stratigraphy of the Wairakei-Tauhara geothermal system has been summarised in Figure 2. Surface geology of the area mostly consists of pyroclastic fall and flow units from the $1.8 \mathrm{ka}$ Taupo eruption, and their reworked sedimentary equivalents (Rosenberg et al., 2009, Bignall et al., 2010; Fig. 2). Underlying the superficial alluvium and tephra deposits is the Oruanui Formation, a sequence of tuffs and ignimbrites that are products of a single eruption from Taupo caldera 26,500 years ago (Wilson, 1993; Wilson, 2001; Bignall et al., 2010). Beneath the Oruanui Formation is the Huka Falls Formation (HFF), which is subdivided into the Upper, Middle and Lower members. The Upper and Lower members mainly consist of relatively impermeable fine-grained lacustrine sedimentary rocks (mudstone, siltstone, sandstone) that form aquitards separating deeper reservoir fluid from shallow groundwater aquifers (Bignall et al., 2010). The Middle HFF on the other hand encompasses pumiceous tuff and conglomerate from reworked ignimbrites and because of its high permeability it functions as an intervening confined aquifer. At Tauhara the HFF is locally interbedded with the Trig Rhyolite (Figure 2).

Underlying HFF is the Waiora Formation, which is split into five members as described by Grindley (1965): the shallowest member, Wa5, is an ignimbrite and tuff; Wa3 and Wa4 are interbedded breccia, tuff, sandstone and siltstone ; Wa2 is a siltstone, and the basal Wa1 is nonwelded/welded ignimbrite that is also referred to as Waiora Ignimbrite. These members are not all present continuously across Wairakei and Tauhara Fields. Rosenberg et al. (2009) proposed a simplification of the Waiora Formation subdivision and grouped members Wa3 and Wa4 into a Wa3-4 member which is the classification used in this study. The Waiora Formation members Wa3-4 and Wa5 are laterally interbedded with the Crowbar and Racetrack Rhyolites (Figure 2).

Underlying the Waiora Formation is the Wairakei Ignimbrite, which is crystal-rich and moderately welded and belongs to the Whakamaru Group of ignimbrites (Rosenberg et al., 2009; Bignall et al., 2010). The Wairakei Ignimbrite is absent in parts of the Tauhara field suggesting some fault control on its distribution (Rosenberg et al., 2009). For the wells used in this study (TH9, TH10, TH12) the Wairakei Ignimbrite is absent in TH9 and TH10, but present in TH12.

At the Wairakei field, the deep stratigraphy beneath the Wairakei Ignimbrite consists of Reporoa Group formations (Tahorakuri and Waikora Formations). Tauhara geothermal wells have not drilled deep enough to test whether they occur in the eastern part of the Wairakei-Tauhara system (Figure 2). The greywacke basement has not been encountered by Wairakei-Tauhara geothermal wells, which have drilled to $\sim 3 \mathrm{~km}$ maximum depth. All further depths in this study are given as metres below rig floor (mRF).

\section{SAMPLING AND ANALYTICAL TECHNIQUES}

Three geothermal wells (TH9, TH10, TH12) were selected for this study based on GNS well reports commissioned by Contact Energy Ltd. 304 samples of drill cuttings were collected downhole across the three wells for portable x-ray fluorescence (pXRF) analysis. Drill cuttings, which are $5 \mathrm{~m}$ composites collected as the well is drilled, were sampled every $20 \mathrm{~m}$ down well. Where no drill cuttings at the required interval existed (e.g. zones of total circulation losses), a sample from the closest available interval was selected. Samples were also taken $5-10 \mathrm{~m}$ either side of lithological boundaries and at least $20 \mathrm{~m}$ beneath casing points. Cutting samples used in $\mathrm{pXRF}$ and lab XRF were cleaned of drilling mud and dried prior to analysis. Sample preparation for pXRF required half a teaspoon of cuttings to be placed inside a SC-4331 sample cup covered with a thin polypropylene film LS-240-2510 (Premier Lab Supply Ltd) with a locking ring to hold the film in place. The average grain size of a sample was $1-6 \mathrm{~mm}$, so for samples that were too coarse a small amount of dry grinding with an agate mortar and pestle was used to reduce the grain size. The coarser grain size is common for samples from shallow depths in geothermal wells. 
An Olympus Innov-X Delta $50 \mathrm{keV}$ Handheld XRF Analyzer gun (Olympux Innov-X 50 KV DP4050CX) manufactured by Olympus was set to "Geochem mode" and mounted in a benchtop stand. Concentrations of major and trace elements were recorded by Innov-X Delta Advanced PC software. Limits of detection for elements analysed by pXRF are in the ppm range, except for $\mathrm{Mg}, \mathrm{Si}$, and $\mathrm{Al}$ at $<1 \%$ and $\mathrm{P}$ at $<0.5 \%$. The following elements were analysed; $\mathrm{Nd}, \mathrm{Pr}$, $\mathrm{Ce}$, La, Ba, Y, Al, Si, P, S, Cl, K, Ca, Ti, V, Cr, Mn, Fe, Co, Ni, Cu, Zn, As, Se, Rb, Sr, Zr, Nb, $\mathrm{Mo}, \mathrm{Ag}, \mathrm{Cd}, \mathrm{Sn}, \mathrm{Sb}, \mathrm{Ta}, \mathrm{W}, \mathrm{Au}, \mathrm{Hg}, \mathrm{Pb}, \mathrm{Bi}$, Th, U. Each scan took one minute with calibration checks made every 30 samples. Elements with low atomic numbers (such as $\mathrm{F}, \mathrm{Na}$ and $\mathrm{Mg}$ ) are either impossible or difficult to measure by current portable XRF technology due to the very weak fluorescence from these elements, which are mostly absorbed by the air between the target and the detector.

Forty-five drill cutting samples (15 from each well), representing different formations, were selected for lab-based XRF analysis. Major elemental oxides were determined on lithium borate fused beads and trace elements obtained from pressed powder pellets. Elemental oxides and trace elements were analysed including $\mathrm{Na}_{2} \mathrm{O}, \mathrm{MgO}, \mathrm{Al}_{2} \mathrm{O}_{3}, \mathrm{SiO}_{2}, \mathrm{P}_{2} \mathrm{O}_{5}, \mathrm{~K} 2 \mathrm{O}, \mathrm{CaO}, \mathrm{TiO}_{2}, \mathrm{MnO}, \mathrm{Fe}_{2} \mathrm{O}_{3}$, $\mathrm{S}, \mathrm{Cl}, \mathrm{V}, \mathrm{Cr}, \mathrm{Co}, \mathrm{Ni}, \mathrm{Cu}, \mathrm{Zn}, \mathrm{Ga}, \mathrm{Ge}$, As, Se, Br, Rb, Sr, Y, Zr, Nb, Mo, Sn, Sb, Te, Ba, La, Ce, $\mathrm{Nd}, \mathrm{Hf}, \mathrm{Ta}, \mathrm{Tl}, \mathrm{Pb}, \mathrm{Bi}, \mathrm{Th}, \mathrm{U}$. Rock standards were not run for $\mathrm{pXRF}$, therefore laboratory XRF was used as calibration to correct the concentration of elements within pXRF samples. A linear regression analysis was employed on each element and all raw pXRF concentrations were multiplied by the slope of the regression line to correct the results (Fig. 3).

\section{RESULTS}

\subsection{Comparison of laboratory and portable XRF methods}

Table 1 and Figure 4 illustrate the comparison between elements from 45 samples that were analysed by both pXRF and lab-based XRF. The pXRF data were collected on cuttings with no preparation and the lab-based XRF data was collected on cuttings crushed to a fine powder using a tungsten carbide ring mill. Comparison of the two techniques reveals that many elements show strong, positive correlations (Spearman correlation coefficient $\left(r_{\mathrm{s}}\right)$ values $>+0.8$ ). For instance, $\mathrm{Ba}\left(r_{\mathrm{s}}=0.93\right)$ and $\mathrm{Zr}\left(r_{\mathrm{s}}=0.89\right)$ are both well correlated (Table 1; Fig. 4). The presence of outliers in the data can skew correlations hence the Spearman rank correlation method was used as it is more robust against outliers, in contrast to the Pearsons product moment correlation method that is sensitive to outliers (Rollinson, 1993; Fig. 4).

Yttrium and $\mathrm{Rb}$ are also well correlated (0.89; Fig. 4; Table 1$)$ whereas $\mathrm{Al}$ is poorly correlated (0.17; Fig. 4; Table 1). Elements with strong positive correlations of at least 0.80 are As, $\mathrm{Ba}, \mathrm{Ca}$, $\mathrm{K}, \mathrm{Nb}, \mathrm{Rb}, \mathrm{Sr}, \mathrm{Y}$, and $\mathrm{Zr}$ (Table 1). Titanium has a strong correlation, but Ti was detected by $\mathrm{pXRF}$ in only four samples. Elements with moderate correlation $\left(r_{\mathrm{s}}=0.5-0.8\right)$ are $\mathrm{Mn}, \mathrm{Mo}, \mathrm{Pb}$, $\mathrm{S}, \mathrm{Si}, \mathrm{Zn}$ and Fe. Elements showing a lack of correlation $\left(r_{\mathrm{s}}<0.5\right)$ are $\mathrm{Al}, \mathrm{Cr}, \mathrm{Cu}, \mathrm{Sb}, \mathrm{Ta}$ and $\mathrm{Th}$. Tin has a perfect negative linear relationship at -1 , yet was only detected in three samples so this result has little significance.

A study by Piercey and Devine (2014) on powdered international reference samples found excellent correlation between lab-based XRF and pXRF for $\mathrm{S}, \mathrm{K}_{2} \mathrm{O}, \mathrm{CaO}, \mathrm{TiO}_{2}, \mathrm{MnO}, \mathrm{Fe}_{2} \mathrm{O}_{3}, \mathrm{Co}$, $\mathrm{Cu}, \mathrm{Pb}, \mathrm{Rb}, \mathrm{Sr}, \mathrm{Ba}, \mathrm{Zr}, \mathrm{Nb}, \mathrm{U}$, As and $\mathrm{Mo}$; moderate correlation for $\mathrm{Al}_{2} \mathrm{O}_{3}, \mathrm{SiO}_{2}$ and $\mathrm{Zn}$ and poor correlation for $\mathrm{MgO}, \mathrm{P}_{2} \mathrm{O}_{5}, \mathrm{~V}, \mathrm{Cr}$ and $\mathrm{Ni}$. Our results are largely consistent with those of Piercey and Devine (2014), with some of the discrepancies (e.g. Mo) most likely related to the very low Mo concentrations in the Tauhara host rocks, compared to those reported in Piercey and Devine (2014).

Therefore, we conclude that $\mathrm{pXRF}$ is reliable for measuring the concentration of many elements in rocks typical of the Taupo Volcanic Zone (As, Ba, Ca, K, Nb, Rb, Sr, Y, Zr, Mn, Mo, Pb, S, Si, 
$\mathrm{Zn}, \mathrm{Fe}$ ), but is not as effective for others ( $\mathrm{Al}, \mathrm{Cr}, \mathrm{Cu}, \mathrm{Sb}, \mathrm{Ta}, \mathrm{Th})$. Generally, the pXRF performs poorly for light elements with low atomic numbers ( $\leq 17$, such as $\mathrm{Na}, \mathrm{Mg}, \mathrm{Al}, \mathrm{Si}, \mathrm{P}, \mathrm{S}$ and $\mathrm{Cl}$ ) (Gazley et al., 2011). Differences in techniques between pXRF and lab-based XRF, such as the lack of a vacuum or helium purge unit in the pXRF gun to help with the detection of light elements, is the likely cause for the poor performance of these elements on the pXRF instrument.

\subsection{Elemental concentrations downhole}

In hydrothermal systems, alteration varies with proximity towards hydrothermal fluid flow pathways, analogous to vein mineralisation in epithermal ore deposits (Warren et al., 2007). Variation of the mobile elements likely reflects hydrothermal alteration, thus indicating zones of high fluid flow presently or in the past. Construction of simple downhole plots of elements enables geochemical trends to be unravelled that show this variation (Gifkins et al., 2005; Peter et al., 2009).

Elements that are relatively mobile during alteration are $\mathrm{Si}, \mathrm{Fe}, \mathrm{Mg}, \mathrm{Ca}, \mathrm{Na}$ as their positive valence and solubility allow them to be more easily transported in hydrothermal solution (Gifkins et al., 2005; Middelburg., 1988). Because of their low ionic potential (charge/radius), the large ion lithophile elements of $\mathrm{Sr}, \mathrm{K}, \mathrm{Rb}$ and $\mathrm{Ba}$ (and sometimes $\mathrm{Th}$ ) also tend to be mobile as fluids migrate (Pearce, 1982). During alteration there are also elements which remain chemically immobile and can be used in classifying and correlating volcanic rocks. Elements that remain relatively immobile during hydrothermal alteration are high field strength elements (HFSE) such as $\mathrm{Ti}, \mathrm{Zr}, \mathrm{Nb}$ and Y (Winchester and Floyd, 1977: Pearce, 1996). Studies on volcanic hosted massive sulphide deposits (e.g. MacLean \& Barrett, 1993) have shown that Al, Ti, the high-field strength elements $\mathrm{Zr}, \mathrm{Nb}, \mathrm{Y}$ as well as $\mathrm{Hf}, \mathrm{Ta}$, Th, heavy rare earth elements $(\mathrm{Lu}, \mathrm{Yb})$ and sometimes Sc, V, Cr, remain relatively immobile during alteration processes (Gifkins et al., 2005). In this way, variations in mobile element concentrations act as geochemical vectors towards areas of fluid flow, whilst immobile elements distinguish the precursor rocks which has been obscured by hydrothermal alteration. In the following section, we describe some of the key variations in immobile and mobile elements noted in the three study wells (Figs. 5, 6 and 7).

\section{TH9 well}

Yttrium concentrations increase from $\sim 12 \mathrm{ppm}$ to $\sim 50 \mathrm{ppm}$ between 460 to $520 \mathrm{mRF}$ with another change in concentration also occurring at approximately $900 \mathrm{mRF}$ (from $\sim 20$ to 13 ppm), which correlates with the logged transition between the Waiora Formation and the Waiora Ignimbrite (Fig. 5). Zirconium also exhibits a change in concentration at this depth, from $\sim 175$ ppm to 125 to $140 \mathrm{ppm}$. Barium concentrations overall generally increase with depth down well, in particular at $450 \mathrm{mRF}$ concentrations increase from approximately 250 to $1000 \mathrm{ppm}$ (Fig. 5). $\mathrm{Rb}, \mathrm{Ba}$ and $\mathrm{Sr}$ exhibit the same step change in concentration at the formation boundary at 900 $\mathrm{mRF}$ although not as sharply. Rubidium, $\mathrm{Ba}$ and $\mathrm{Sr}$ are relatively mobile elements likely to be significantly mobilised during hydrothermal alteration (Gifkins et al., 2005). However, this step change is most likely related to host rock lithology variations rather than hydrothermal alteration. Arsenic displays constant concentrations of $\sim 13 \mathrm{ppm}$, but values as high as $150 \mathrm{ppm}$ are noted within and below the Huka Falls Formation (cap of system) and at the bottom of TH9 at locations which correlate with recognised hydrothermal feed zones. Calcium concentrations are relatively constant at $\sim 1.5 \mathrm{wt} \%$, but concentrations as high as $8 \mathrm{wt} \%$ occur at $\sim 840-860 \mathrm{mRF}$ which are likely related to an increased abundance of hydrothermal calcite that was noted in visual logging of cuttings at 835-860 mRF (Milicich et al., 2008). A further increase in Ca concentration occurs between $1.5 \%$ and $2.5 \%$ towards the bottom of TH9. Strontium also shows a similar downhole 
pattern where at $840 \mathrm{mRF}$ concentrations increase to $270 \mathrm{ppm}$. Potassium increases with depth from 0 to $900 \mathrm{~m}$, and then remains constant at approximately $2500 \mathrm{ppm}$ to the bottom of the well.

\section{TH10 well}

Multiple major and trace elements, including $\mathrm{Si}, \mathrm{K}, \mathrm{Ca}, \mathrm{Fe}, \mathrm{Ba}, \mathrm{Y}, \mathrm{Rb}, \mathrm{Sr}, \mathrm{Zr}$ and $\mathrm{Nb}$ all show a clear change in concentration between 1180 and $1200 \mathrm{~m}$, which is $\sim 85 \mathrm{~m}$ above the logged transition between the Waiora 1 ignimbrite (Wa1) and a lithic-crystal breccia (Fig. 6, and supplementary data). A more subtle change in elements $\mathrm{Y}$ and $\mathrm{Zr}$, also occurs at the logged formation boundary. Changes in $\mathrm{K}$ and $\mathrm{Ca}$ generally correlate with logged formation boundaries down hole. Rubidium also shows other distinct changes in concentration down hole which generally correlate with logged formation boundaries (Fig. 6). However, some distinct Rb changes occur which do not appear to correlate with recognised formation boundaries, or variations in other trace element concentrations such as Y, instead correlating with a recognized feed zone at $1860 \mathrm{~m}$ and a similar increase in K. Sulfur displays elevated concentrations at the top of the Crowbar Rhyolite Lava and Huka Falls Formation, and is below detection limit for most samples within the well. Arsenic is elevated at the base of the Huka Falls Formation and minor increases around hydrothermal feed zones are also measured.

\section{TH12 well}

Yttrium shows significant variability between 20 and $60 \mathrm{ppm}$, with changes appearing to correlate with transitions between logged formations (Fig. 7). Changes in $\mathrm{Zr}$ concentration downhole follow a similar pattern to $\mathrm{Y}$, at $\sim 900 \mathrm{mRF} \mathrm{Zr}$ concentration varies from $\sim 140 \mathrm{ppm}$ to $\sim 190 \mathrm{ppm}$ correlating with the logged formation boundary. Rubidium displays a clear break at $1040 \mathrm{~m}$ where $\mathrm{Rb}$ is elevated in concentration (at the same location as the recognised feed zone). Potassium displays two clear changes in concentration down hole, a major change at $1040 \mathrm{~m}$ where $\mathrm{K}$ ppm increases in the middle of the Waiora 1 ignimbrite (Wa1) which correlates with a recognised feed zone and a minor break at $330 \mathrm{~m}$ where the Huka Formation transitions into the underlying volcaniclastic rocks. Changes in calcium concentration with depth are similar to $\mathrm{K}$ and mirrors that of Sr (Fig. 7). Silicon is in higher concentrations from the top of the Waiora Formation with depth down hole, displaying a clear break at the boundary of the Huka Falls and Waiora Formations, reflecting the change in lithology between lake sediments and volcaniclastic rocks.

\section{DISCUSSION}

As described in the results above, significant variations in trace and major element concentrations occur in each of the three drill holes assessed in this study. Some of these variations correlate with logged lithological boundaries and hydrothermal feed zones, while other variations occur where lithological differences have not been previously recognised. In this section, we discuss the potential causes and significance of geochemical variations in the three Tauhara geothermal wells.

\subsection{Discerning lithological boundaries and variations}

In TH9, TH10 and TH12 the clear change in concentrations of Y and Zr (both relatively immobile high field strength elements unlikely to be significantly mobilized by hydrothermal fluids; Winchester and Floyd, 1977; Pearce, 1996) are ideal in recognising formation boundaries that may be harder to ascertain visually. In drill hole TH10, multiple elements all show a clear major change in concentration at $1180-1200 \mathrm{mRF}, \sim 85 \mathrm{~m}$ above the logged transition between the Waiora 1 ignimbrite (Wa1) and a lithic-crystal breccia. The covariation of all of these elements strongly suggests that these elements are varying as a function of varying lithology at this location, not as a result of hydrothermal alteration alone. A smaller change in concentration in $\mathrm{Y}$ and $\mathrm{Zr}$ at the logged boundary, suggest that the logged boundary is real, but a previously unrecognised 
formation boundary occurs $\sim 85$ metres above the logged boundary. Hence we suggest that at this location there is a sub-unit in the Wa1 formation.

These results demonstrate that variations in the concentrations of immobile elements such as $\mathrm{Zr}$ and $\mathrm{Y}$ can be used to identify lithological boundaries as evidenced by the covariation in elemental concentrations with logged lithological boundaries. However, significant variations in elemental concentrations are also noted within logged lithological units. For example, in TH9, Y displays sharp changes in concentration within the rocks logged as the Waiora Formation. We interpret these variations to represent slight changes in lithology (i.e. sub units) which are difficult to recognise by visual logging alone. There are also distinct "zig zag" trends within the $1000 \mathrm{~m}$ thick Waiora Ignimbrite unit (marked by shorter dashed lines on Figures 5 and 6) that are displayed by $\mathrm{Rb}, \mathrm{Ba}$ and to some extent $\mathrm{Y}$. This trend in the chemical data suggests some internal stratigraphic variation, possibly individual volcanic flow packages (resulting from individual volcanic eruptions within a larger eruption sequence) within the larger Waiora Ignimbrite.

As outlined above, many of the chemical variations determined downhole correlate with the lithological transitions identified by traditional logging of cuttings. Thus portable XRF can be used to refine lithological sequences and supplement traditional visual logging, even in "real time" while drilling is occurring. If particular lithologies have distinctive chemical compositions, or distinctive trends within a lithological package, then the chemistry could be used to correlate units between drill holes. Such an approach could be supported by multivariate statistical techniques and chemostratigraphic approaches (e.g. Pettijohn, 1975; Pearce and Jarvis, 1992; Pearce et al., 1999) in addition to visual and graphical assessment of data.

\subsection{Discerning hydrothermal alteration}

Detecting hydrothermal alteration using lithogeochemistry is a standard approach in the study of hydrothermal ore deposits (Warren et al., 2007). In active geothermal systems, identifying hydrothermal alteration may point to the location of inactive or active zones of high fluid flow (i.e., well feed zones), giving information about how feed zones in the geothermal system have changed over time. In this section, we highlight geochemical signatures which appear to correlate with the location of current hydrothermal feeed zones.

Potassic alteration (K-metasomatism, manifested as the formation of adularia and illite) occurs in the major upflow zone of geothermal systems as ascending solutions cool (Simmons and Browne, 2000). Phyllic (or illite) alteration (H-K metasomatism) occurs in the outer halo from the main upflow zone as K-feldspar abundance decreases, and argillic alteration occurs in the halo beyond phyllic alteration as clay minerals become prevalent (Kühn, 2004). In TH10, at 1860 mRF (Fig. 7) there is a large increase in $\mathrm{Rb}$ concentration which is the location of a recognised main feed zone. Potassium and $\mathrm{Ba}$ show an increase at the same location whilst $\mathrm{Sr}$ shows a decrease. The mobility of $\mathrm{Rb}, \mathrm{K}$ and $\mathrm{Ba}$ may reflect enhanced potassic hydrothermal alteration and the potential formation of abundant illite (and/or adularia), while $\mathrm{Sr}$ removal is consistent with the destruction of Ca-bearing plagioclase (as $\mathrm{Sr}$ substitutes for $\mathrm{Ca}$ ). Therefore, it is possible that andesine (Cabearing plagioclase) has been altered and replaced by illite. Rubidium, as well as K, also shows other distinct changes in concentration down hole which generally correlate with logged formation boundaries (Figs. 5-7). Thus, variations in Rb concentrations alone cannot be used to identify potassic hydrothermal alteration as such, but do indicate fluid flow due to the correlation with feed zones.

Molar ratio plots enable alteration trends to be visualised graphically (Davies \& Whitehead, 2011). A fully $\mathrm{K}$-feldspar $\left(\mathrm{KAlSi}_{3} \mathrm{O}_{8}\right)$ altered rock is a 1:1 ratio of $\mathrm{K}: \mathrm{Al}$ and a fully albitized $\left(\mathrm{NaAlSi}_{3} \mathrm{O}_{8}\right)$ rock is also 1:1 of Na:Al. Figure 9 reveals that there is some Na-depletion with varying amounts 
of $\mathrm{K} / \mathrm{Al}$ enrichment and depletion, and those Na-depleted samples probably have illite, illitesmectite or smectite minerals present (Halley, 2014). K/Al ratios up to 0.45 may represent phengitic white mica whilst $\mathrm{K} / \mathrm{Al}$ ratios greater than 0.45 suggest an additional potassic mineral is present (Halley, 2014). The rocks in the Tauhara suite display varying degrees of Na-depletion and a spectrum of $\mathrm{K} / \mathrm{Al}$ ratios from 0.05 to 0.49 . Figure 9 suggests that on a whole rock basis, alteration styles vary between argillic (depleted in both $\mathrm{Na}$ and $\mathrm{K}$ ), potassic and phyllic. This trend suggests the bulk of the wells are close to an upflow zone, in particular TH9. However TH10 shows the most significant variation in $\mathrm{K} / \mathrm{Al}$ and $\mathrm{Na} / \mathrm{Al}$ ratios, indicating that it may have experienced the greatest influence from $\mathrm{H}^{+}$metasomatism by low $\mathrm{pH}$ fluids. According to alteration logs, clay alteration is also greatest in TH10, but propylitic alteration develops at shallower depths in TH12 compared to TH10.

In wells TH9 and TH10, arsenic is elevated at the base of the Huka Falls Formation which is the cap for the deeper aquifer/reservoir and minor increases around recognised hydrothermal feed zones are also measured. Arsenic is a ubiquitous element in the geothermal fluids of the Taupo Volcanic Zone, and it thus might be expected that arsenic would therefore delineate hydrothermal fluid flow pathways and feed zones. However, it has been demonstrated that the arsenic concentrations of hydrothermal fluids in the deep part of geothermal systems in the TVZ are similar to those in fluids emitted at the surface, suggesting that only limited arsenic precipitation occurs in the subsurface (Simmons and Browne, 2007; Simmons and Browne, in review). Thus, arsenic anomalies in the subsurface appear to be limited, and likely reflect only locations where As has become insoluble which is most likely to occur in oxidized, low $\mathrm{pH}$ hydrothermal fluids (Ballantyne and Moore, 1988) such as those which might occur near surface where mixing of surface-influenced steam-heated waters and deep reservoir fluids might occur.

The downhole distribution pattern of $\mathrm{Ca}$ and $\mathrm{Sr}$ likely reflects the precipitation of calcite in geothermal systems is typically controlled by boiling, fluid mixing or hydrolysis (Simmons and Christenson, 1994). While recognising calcite abundance during logging is simple (due to the reactivity of calcite with weak acid) portable XRF technology may allow for the quantification of calcite. Similarly, the presence of silicification may also be possible to identify by comparing the ratio of $\mathrm{Si}$ to $\mathrm{Al}$ or other immobile elements, if the amount of $\mathrm{Si}$ in the original host rock can be estimated.

\section{CONCLUSIONS}

The results presented above demonstrate that portable XRF analyzers produce accurate data for many elements directly from geothermal cuttings, with little sample preparation required. Thus, pXRF can be routinely used during geothermal drilling and subsequent logging activities to accurately measure the chemical composition of geothermal cuttings. Abrupt changes in the concentration of immobile elements (such as $\mathrm{Y}, \mathrm{Zr}$ and $\mathrm{Nb}$ ) with depth downhole, correlate with logged lithological boundaries. Other abrupt changes in immobile element concentrations are interpreted to represent previously unrecognised lithological boundaries, as lithological variations are easily obscured by hydrothermal alteration. Therefore portable XRF can be used to develop a chemostratigraphy in geothermal fields analogous to the way that chemostratigraphy is used to aid correlation of lithologies in sedimentary basins.

The concentration of some relatively mobile elements, such as $\mathrm{Ba}, \mathrm{K}, \mathrm{Ca}, \mathrm{As}$, and $\mathrm{Rb}$ also appear to correlate to formation boundaries. However there are some distinct variations in the concentrations of these elements which do not coincide with recognised formation boundaries, or variations in the concentrations of immobile elements, and instead correlate with known areas of fluid flow (feed zones). Therefore recognition of changes in the concentration of these elements within the same lithology (identified using immobile elements) can be used to identify zones of hydrothermal fluid flow. 
We suggest that portable XRF should be integrated as a routine practice in geothermal exploration and drilling due to the low cost and availability of units to purchase or rent, ease of use and ease of sample preparation, rapid analyses which permit chemical characterisation at the same rate as drilling proceeds, and finally, because the data adds significant value to that collected by traditional visual logging.

\section{ACKNOWLEDGEMENTS}

We would like to acknowledge Contact Energy for access to the drill cutting samples and thank Sophie Milloy for her valuable help, GNS Wairakei for their assistance and contribution, and The Sir Hugh Kawharu Foundation, AUSIMM and The Todd Academic Awards for Excellence for making this research possible.

\section{REFERENCES}

Ballantyne J.M., Moore, J.N., 1988. Arsenic geochemistry in geothermal systems. Geochimica et Cosmochimica Acta 52, 475-483.

Bibby, H.M., Caldwell, T.G., Davey, F.J., Webb, T.H., 1995. Geophysical evidence on the structure of the Taupo Volcanic Zone and its hydrothermal circulation. Journal of Volcanology and Geothermal Research 68, 29-58.

Bignall, G., Milicich, S., Ramirez, E., Rosenberg, M., Kilgour, G., Rae, A., 2010. Geology of the Wairakei-Tauhara geothermal system, New Zealand. Proceedings of the World Geothermal Congress 2010, Bali, Indonesia.

Brand, N.W., Brand, C.J., 2014. Performance comparison of portable XRF instruments. Geochemistry: Exploration, Environment, Analysis 14 (2), 125-138.

Davies, J. F., Whitehead, R. E., 2011. Alkali/Alumina molar ratio trends in altered granitoid rocks hosting porphyry and related deposits. Exploration and Mining Geology, 19 (1 \& 2), 13-22.

Dufresne, A., 2014. An overview of rock avalanche-substrate interactions. In K. Sassa, P. Canuti, Y. Yin (Eds.), Landslide science for a safer geoenvironment vol. 1: The international programme on landslides. Springer, Heidelberg.

Gazley, M.F., Vry, J.K., du Plessis, E., Handler, M.R., 2011. Application of portable X-ray fluorescence analyses to metabasalt stratigraphy, Plutonic Gold Mine, Western Australia. Journal of Geochemical Exploration 110, 74-80.

Gazley, M.F., Fisher, L.A., 2014. A review of the reliability and validity of portable X-ray fluorescence spectrometry ( $\mathrm{pXRF}$ ) data. In Mineral Resource and Ore Reserve Estimation The AusIMM Guide to Good Practice, second ed. The Australasian Institute of Mining and Metallurgy.

Gifkins, C., Herrmann, W. \& Large, R., 2005. Altered volcanic rocks: A guide to description and interpretation. Centre for Ore Deposit Research. University of Tasmania, Australia.

Goodale, N., Bailey, D.G., Jones, G.T., Prescott, C., Scholz, E., Stagliano, N., Lewis, C., 2012. pXRF: A study of inter-instrument performance. Journal of Archaeological Science 39 (4), 875-883. 
Gravley, D.M., Wilson, C.J.N., Rosenberg, M.D., Leonard G.S., 2006. The nature and age of Ohakuri Formation and Ohakuri Group rocks in surface exposures and geothermal drillhole sequences in the central Taupo Volcanic Zone, New Zealand. New Zealand Journal of Geology and Geophysics 49, 305-308.

Grindley, G.W., 1965. The geology, structure and exploitation of the Wairakei Geothermal Field, Taupo, New Zealand. New Zealand Geological Survey, Wellington, New Zealand, Bulletin $75,131 \mathrm{pp}$.

Halley, S., 2014. Calculated mineralogy and its applications. In Mineral Resource and Ore Reserve Estimation - The AusIMM Guide to Good Practice, second ed. The Australasian Institute of Mining and Metallurgy.

Hedenquist, J.W., 1991. Boiling and dilution in the shallow portion of the Waiotapu geothermal system, New Zealand. Geochimica et Cosmochimica Acta 55, 2753- 2765.

Hedenquist, J.W., Lowenstern, J.B., 1994. The role of magmas in the formation of hydrothermal ore deposits. Nature 370, 519-526.

Hunt, T.M., Graham, D.J., 2009. Gravity changes in the Tauhara sector of the Wairakei-Tauhara geothermal field, New Zealand. Geothermics 38, 108-116.

Jones. M.C., Williams-Thorpe. O., Potts. P.J., Webb, P.C., 2005. Using field-portable XRF to assess geochemical variations within and between dolerite outcrops of Preseli, south Wales. Geostandards and Geoanalytical Research 29 (3), 251-269.

Kühn, M., 2004. Reactive flow modeling of hydrothermal systems. Lecture notes in Earth Sciences, 103. Springer.

Libbey, R.B., William-Jones, A.E., 2015. Applications of downhole lithogeochemistry to geothermal exploration. GRC Transactions 39, 451-463.

MacLean, W.H., Barrett, T.J., 1993. Lithogeochemical techniques using immobile elements. Journal of Geochemical Exploration 48, 109-133.

Middelburg, J.J., Van Der Weijden, C.H., Woittiez, J.R.W., 1988. Chemical processes affecting the mobility of major, minor and trace elements during weathering of granitic rocks. Chemical Geology 68, 253-273.

Milloy, S.M., Wei Lim, Y., 2012. Wairakei-Tauhara pressure regime update. Proceedings of the 34th New Zealand Geothermal Workshop 2012, New Zealand.

Milicich, S. D., Rosenberg, M. D., Ramirez, L. E. \& Kilgour, G. N. (2008). Geology of Exploration Well TH9 Tauhara Geothermal Field (Consultancy Report 2008/56). Institute of Geological and Nuclear Sciences.

Pearce, J.A., 1982. Trace element characteristics of lavas from destructive plate boundaries. In Andesites: orogenic andesites and related rocks, R.S. Thorpe (ed.), 525-48. Chichester: Wiley.

Pearce, T.J., Jarvis, I., 1992. Applications of geochemical data to modeling sediment dispersal patterns in distal turbidites: Late Quaternary of the Madeira Abyssal Plain. Journal of Sedimentary Petrology 62, 1112-1129.

Pearce, J. A., 1996. A user's guide to basalt discrimination diagrams. In D.A. Wyman (ed.), Trace element geochemistry of volcanic rocks: Applications for massive sulphide exploration. Geological Association of Canada, Short Course Notes 12, 79-113. 
Pearce, T.J., Besley, B.M., Wray, D.S., Wright, D.K., 1999. Chemostratigraphy: a method to improve interwell correlation in barren sequences - a case study using onshore Duckmantian/Stephanian sequences (West Midlands, U.K.). Sedimentary Geology 124, 197220.

Peter, J.M., Mercier-Langevin, P., Chapman, J.B., 2009. Application of field portable x-ray fluorescence spectrometers in mineral exploration, with examples from the Abitibi Greenstone Belt. In In Lentz, D.R., Thorne, K.G., Beal, K., (eds.), Proceedings of the 24th International Applied Geochemistry Symposium (IAGS), Fredericton, New Brunswick, Canada.

Pettijohn, F.J., 1975. Sedimentary Rocks, third ed. Harper Row, New York.

Piercey, S.J., Devine, M.C., 2014. Analysis of powdered reference materials and known samples with a benchtop, field portable x-ray fluorescence (pXRF) spectrometer: evaluation of performance and potential applications for exploration lithogeochemistry. Geochemistry: Exploration, Environment, Analysis 14 (2), 139-148.

Potts, P.J., Bowles, J.F.W., Reed, S.J.B., Cave, M.R., 1995. Microprobe Techniques in Earth Sciences. Chapman and Hall, London.

Potts, P.J., Bernardini, F., Jones, M.C., Williams-Thorpe, O., Webb, P.C., 2006. Effects of weathering on in situ portable x-ray fluorescence analyses of geological outcrops: Dolerite and rhyolite outcrops from the Preseli Mountains, South Wales. X-Ray Spectrometry 35, 818.

Risk, G.F., Raynet, H.H., Stagpoole, V.M., Graham, D.J., Dawson, G.B., Bennie, S.J. 1984. Electrical resistivity survey of the Wairakei geothermal field. Rep. 200, Geophysical Division, Department of Scientific and Industrial Research, Wellington, New Zealand.

Rollinson, H.R., 1993. Using geochemical data: Evaluation, presentation, interpretation.: Longman, Essex, New York, USA.

Rosenberg, M.D., Bignall, G., Rae, A.J., 2009. The geological framework of the WairakeiTauhara Geothermal System, New Zealand. Geothermics 38, 72-84.

Rosenberg, M., Wallin, E., Bannister, S., Bourguignon, S., Sherburn, S., Jolly, G., Links, F., 2010. Tauhara Stage II Geothermal Project: Geoscience Report. GNS Science Consultancy Report 2010/138, 318pp.

Shindo, D., Oikawa, T., 2002. Analytical electron microscopy for materials science. SpringerVerlag, Tokyo.

Simmons, S.F., Christenson, B., 1994. Origins of calcite in a boiling geothermal system. American Journal of Science 294, 361-400.

Simmons, S.F., Browne, P.L., 2000. Hydrothermal minerals and precious metals in the Broadlands-Ohaaki geothermal system: Implications for understanding low-sulfidation epithermal environments. Economic Geology 95, 971-999.

Simmons, S.F., White, N.C., John, D.A., 2005. Geological characteristics of epithermal precious and base metal deposits. Economic Geology 100, 485-522.

Simmons, S.F., Brown, K.L., 2007. The flux of gold and related metals through a volcanic arc, Taupo Volcanic Zone, New Zealand. Geology 35 (12), 1099-1102. 
Steiner, A., 1977. The Wairakei geothermal area, North Island, New Zealand: Its subsurface geology and hydrothermal rock alteration. New Zealand Geological Survey, Bulletin 90, 134 pp.

Warren, I., Simmons, S.F., Mauk, J.L., 2007. Whole-rock geochemical techniques for evaluating hydrothermal alteration, mass changes, and compositional gradients associated with epithermal Au-Ag mineralization. Economic Geology 102, 923-948.

Wilson, C.J.N., 1993. Stratigraphy, chronology, styles and dynamics of late Quaternary eruptions from Taupo volcano. Philosophical Transactions of the Royal Society, London A343, 205306.

Wilson, C.J.N., 2001. The 26.5 ka Oruanui eruption, New Zealand: An introduction and overview. Journal of Volcanology and Geothermal Research 112, 133-174.

Winchester, J. A., Floyd, P. A., 1977. Geochemical discrimination of different magma series and their differentiation products using immobile elements. Chemical Geology 20, 325-343.

\section{Figures}

Fig. 1. Map of the Tauhara geothermal field, the southeastern part of the Wairakei-Tauhara geothermal system (after Rosenberg et al., 2009). Well used for this study are indicated by yellow circles; TH9 (central), TH10 (south) and TH12 (northeast). The field boundary is defined by an electrical resistivity survey (to a depth of $500 \mathrm{~m}$ ) from Risk et al. (1984) and is shown by the light grey shaded area. DEM is from the GNS active fault database (http://data.gns.cri.nz).

Fig. 2. Stratigraphic units of the Wairakei and Tauhara geothermal fields (after Rosenberg et al., 2009).

Fig. 3. Graph showing Barium concentrations determined by both $\mathrm{pXRF}$ and laboratory XRF. The 45 laboratory XRF results were used to generate a calibration line from which the pXRF results could be corrected.

Fig. 4. Panel of correlation plots showing the correlation between the lab-based technique (x-axis) and portable technique (y-axis) for x-ray fluorescence.

Fig. 5. Variations with depth in element concentrations (Y, Zr, Rb, Ba, As, Ca) for TH9. Note fluctuations in concentrations of $\mathrm{Y}, \mathrm{Zr}, \mathrm{Rb}$ and $\mathrm{Ba}$ within the Waiora Formation and Waiora Ignimbrite, which are interpreted to reflect individual packages of volcaniclastic material or input of material from different states of volcanic eruptions. $\mathrm{Rb}$ and $\mathrm{Ba}$ fluctuations may also represent hydrothermal alteration. Red arrows are feed zones, thick arrows are major feed zones, thin arrows are minor feed zones. Coloured dots represent samples.

Fig. 6. Variations with depth in element concentrations (Y, Zr, Rb, K, Sr, Ca) for TH10. Note the difference in concentration in the immobile elements $\mathrm{Y}$ and $\mathrm{Zr}$, and the mobile elements $\mathrm{Rb}, \mathrm{K}, \mathrm{Sr}$ and Ca particularly at $535 \mathrm{mRF}, 1200 \mathrm{mRF}, 1650 \mathrm{mRF}$ and $1875 \mathrm{mRF}$. Red arrows are feed zones. Coloured dots represent samples.

Fig. 7. Variations with depth in element concentrations (Y, Zr, Rb, K, Sr, Si) for TH12. Logged stratigraphy from GNS well logs is on the left. Red arrows are feed zones. Coloured dots represent samples.

Fig. 8. Plot showing Na/Al vs K/Al from laboratory XRF results. 
Table 1. Lab based XRF and portable XRF correlation matrix (Spearman method) of 13 selected elements.

Supplementary Figure. Downhole variations in element concentrations in drillholes TH9, TH10 and TH12. Logged downhole stratigraphy from GNS well logs is on the left. Solid grey lines are logged lithology boundaries, dashed grey lines indicate elemental concentration differences. Red arrows are identified feed zones, thick arrows are major feed zones, thin arrows are minor feed zones (Contact Energy Ltd). 


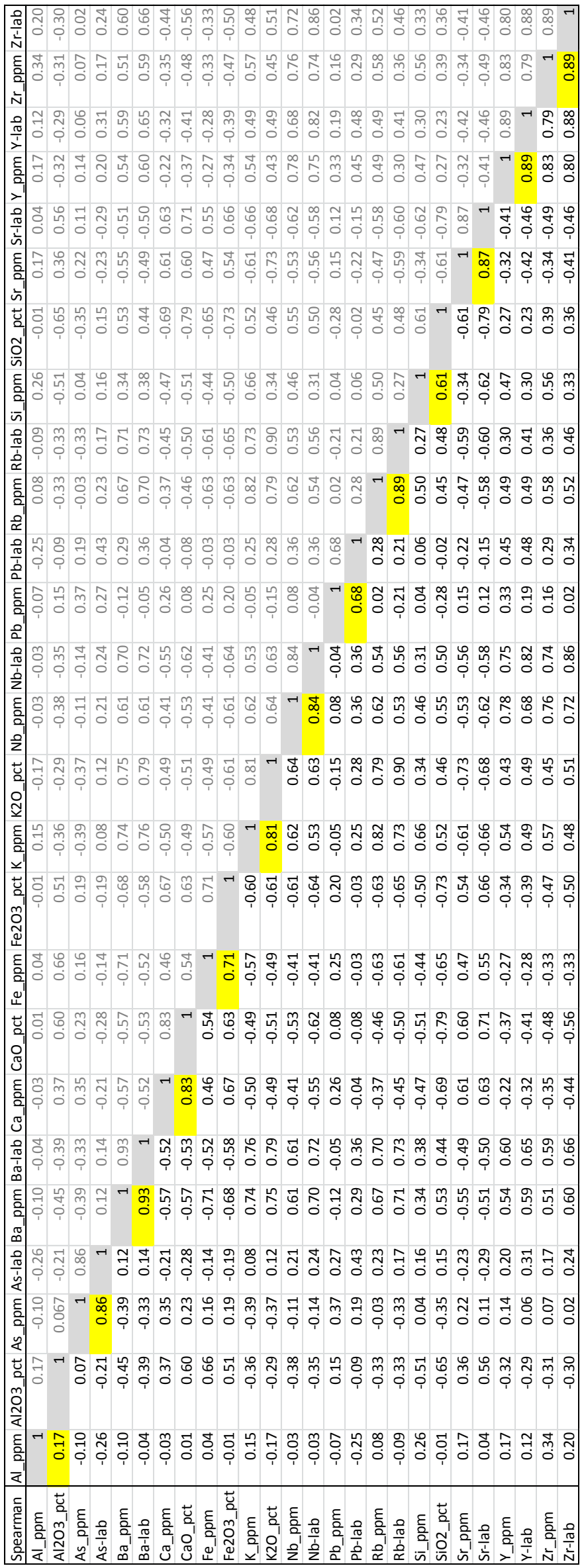




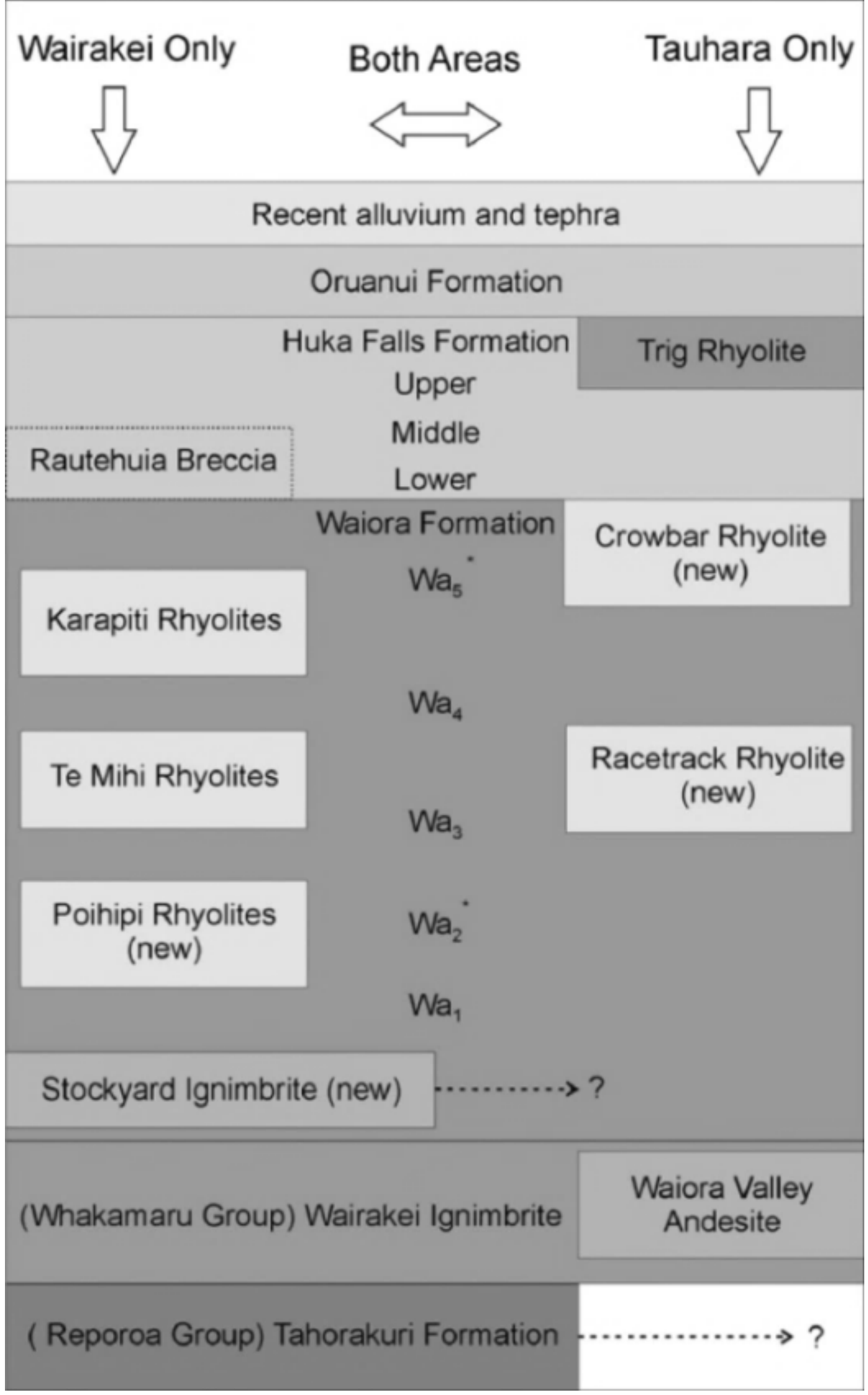



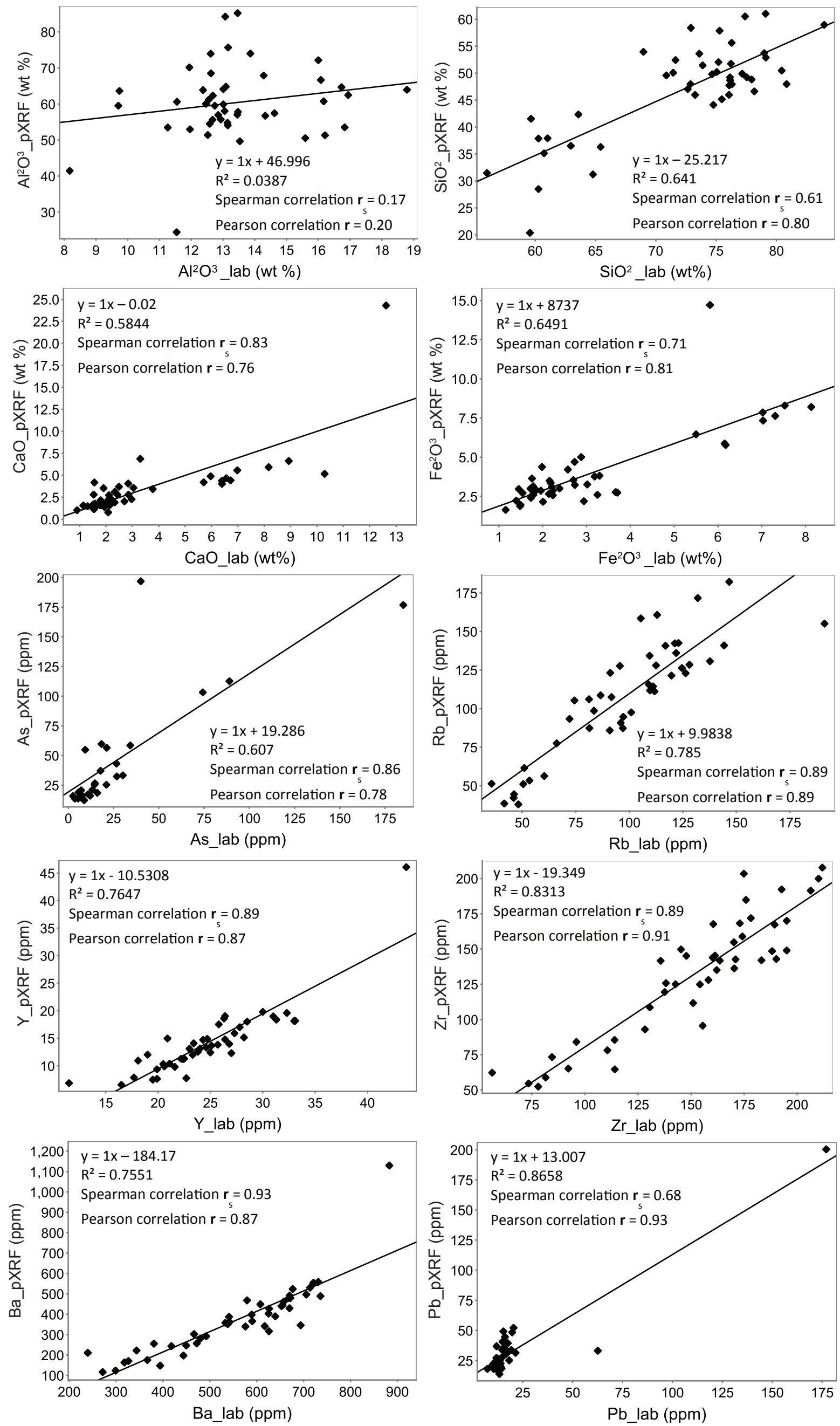


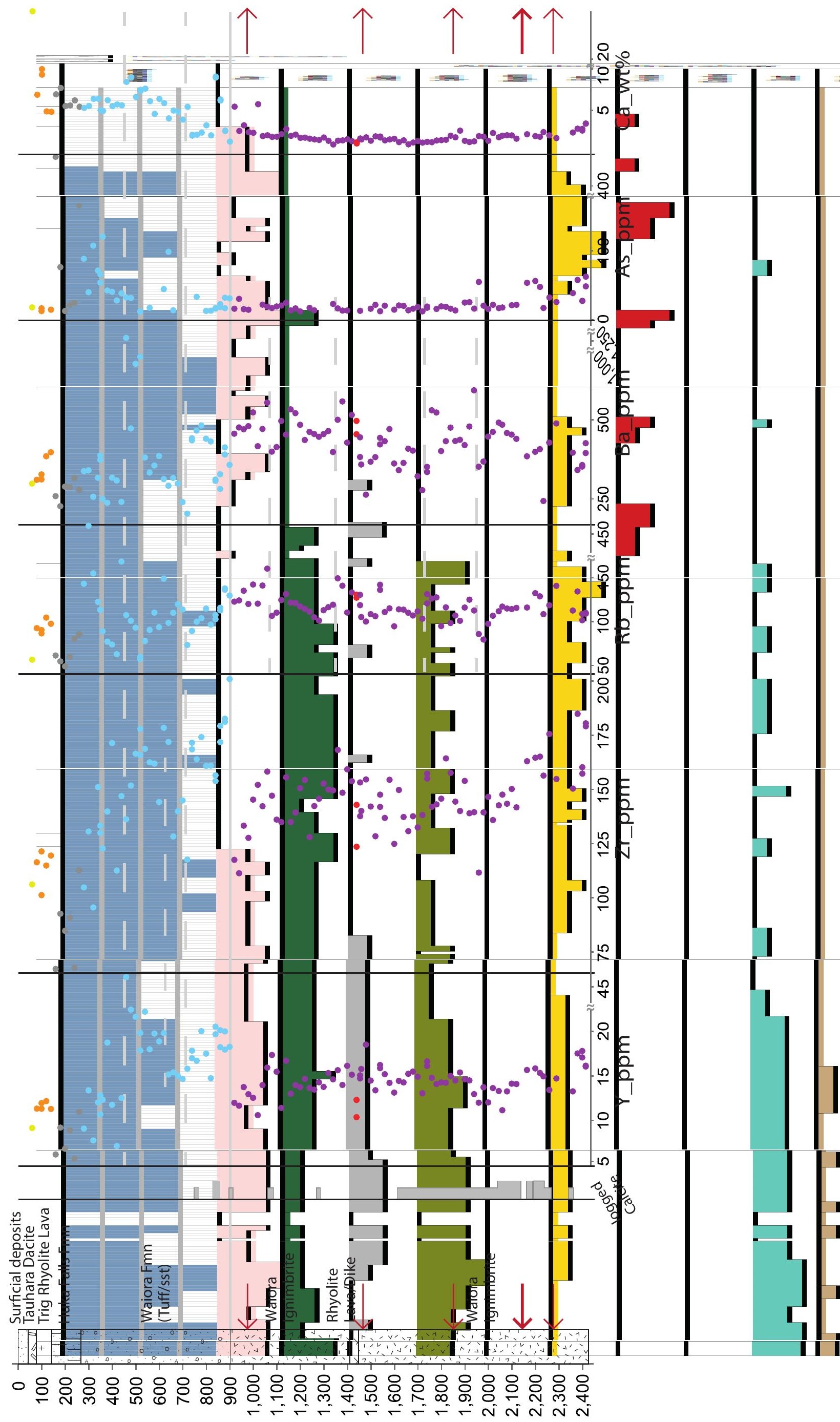

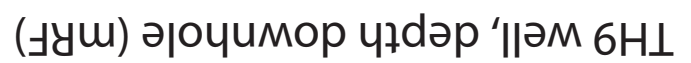




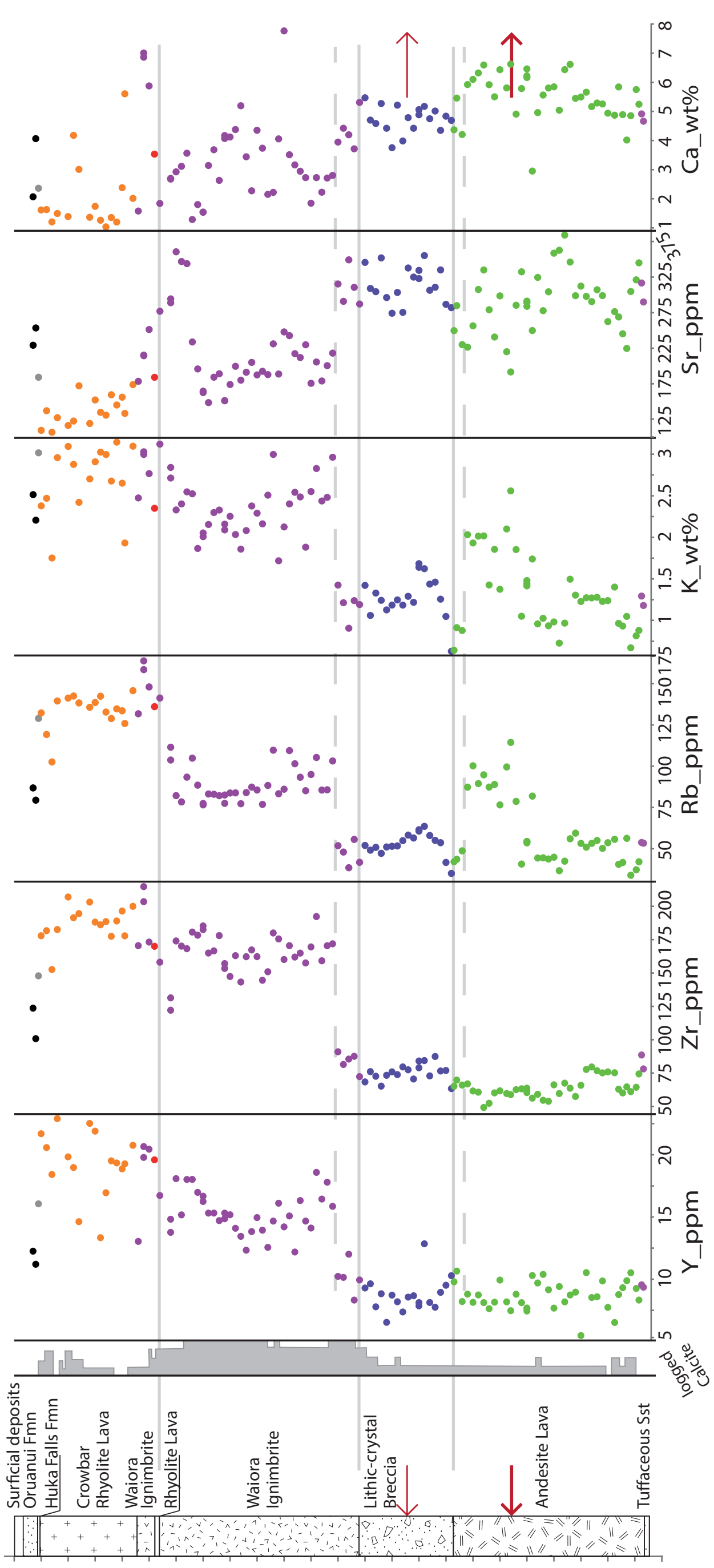

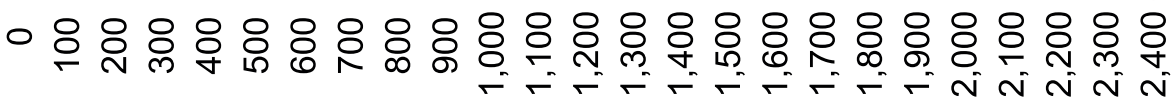


Figure $7=-5$

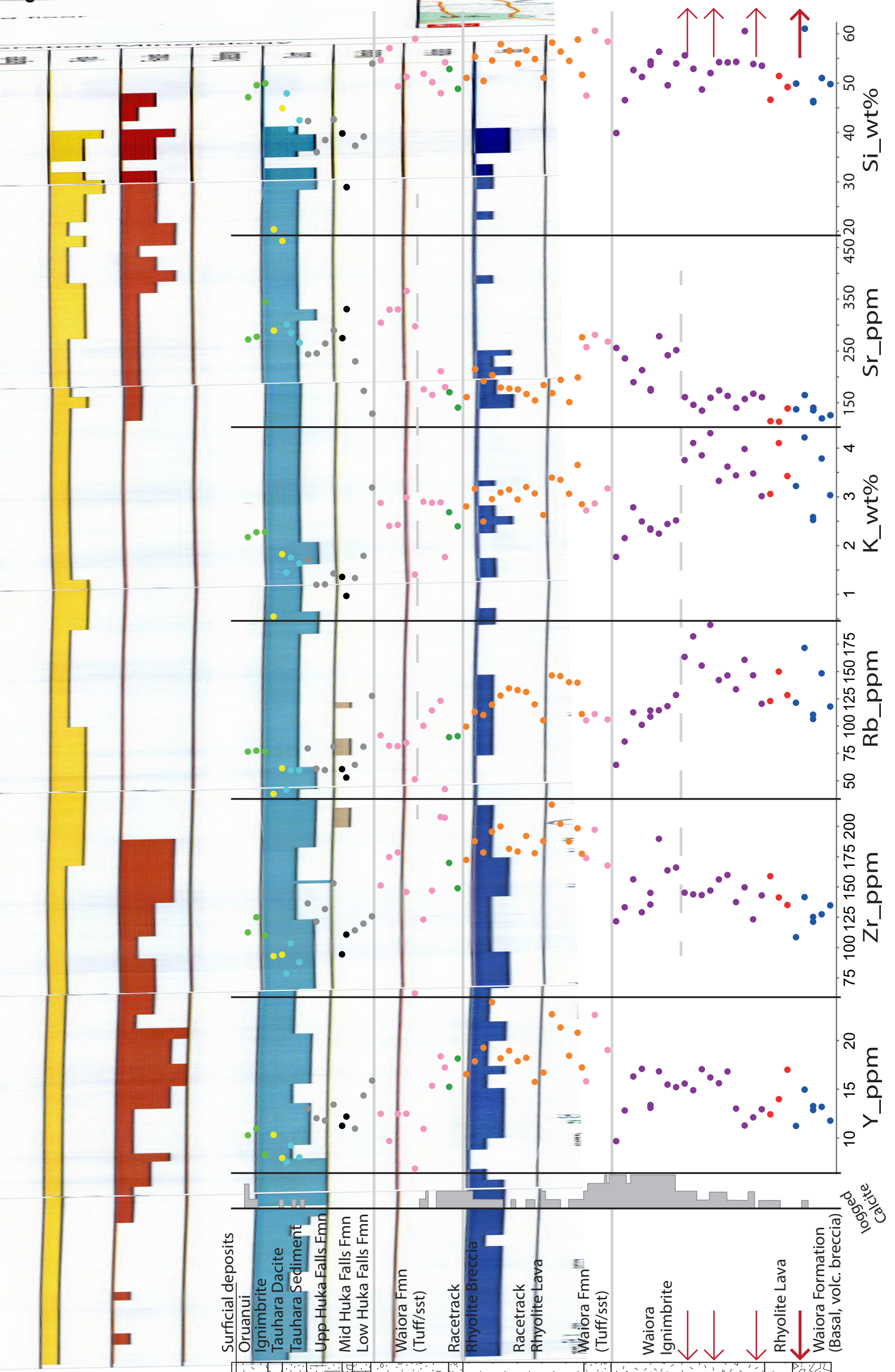

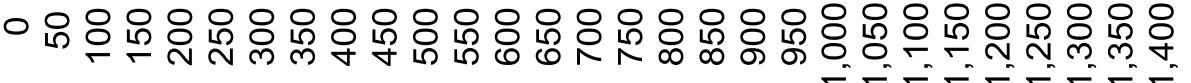


Figure 8

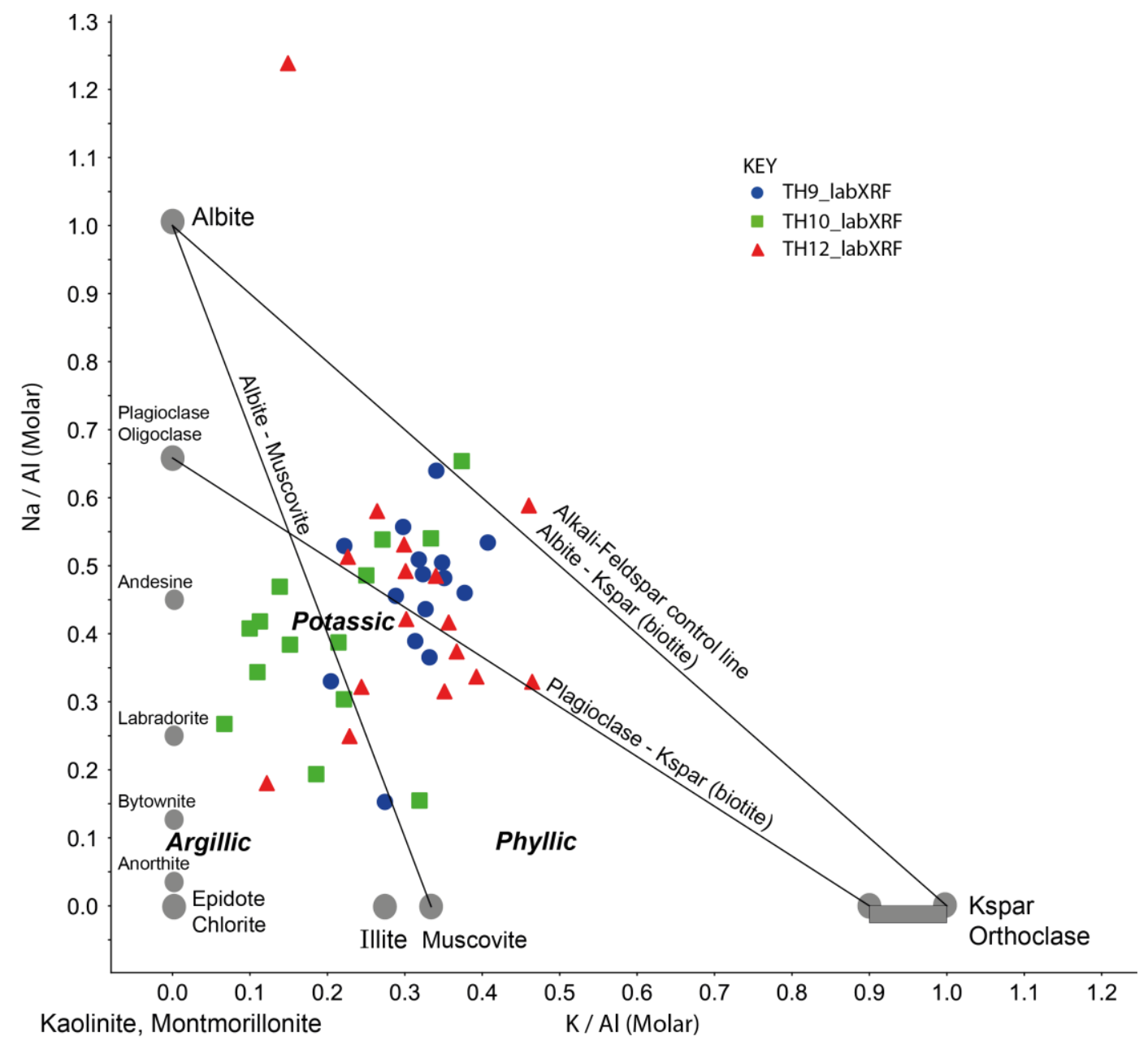




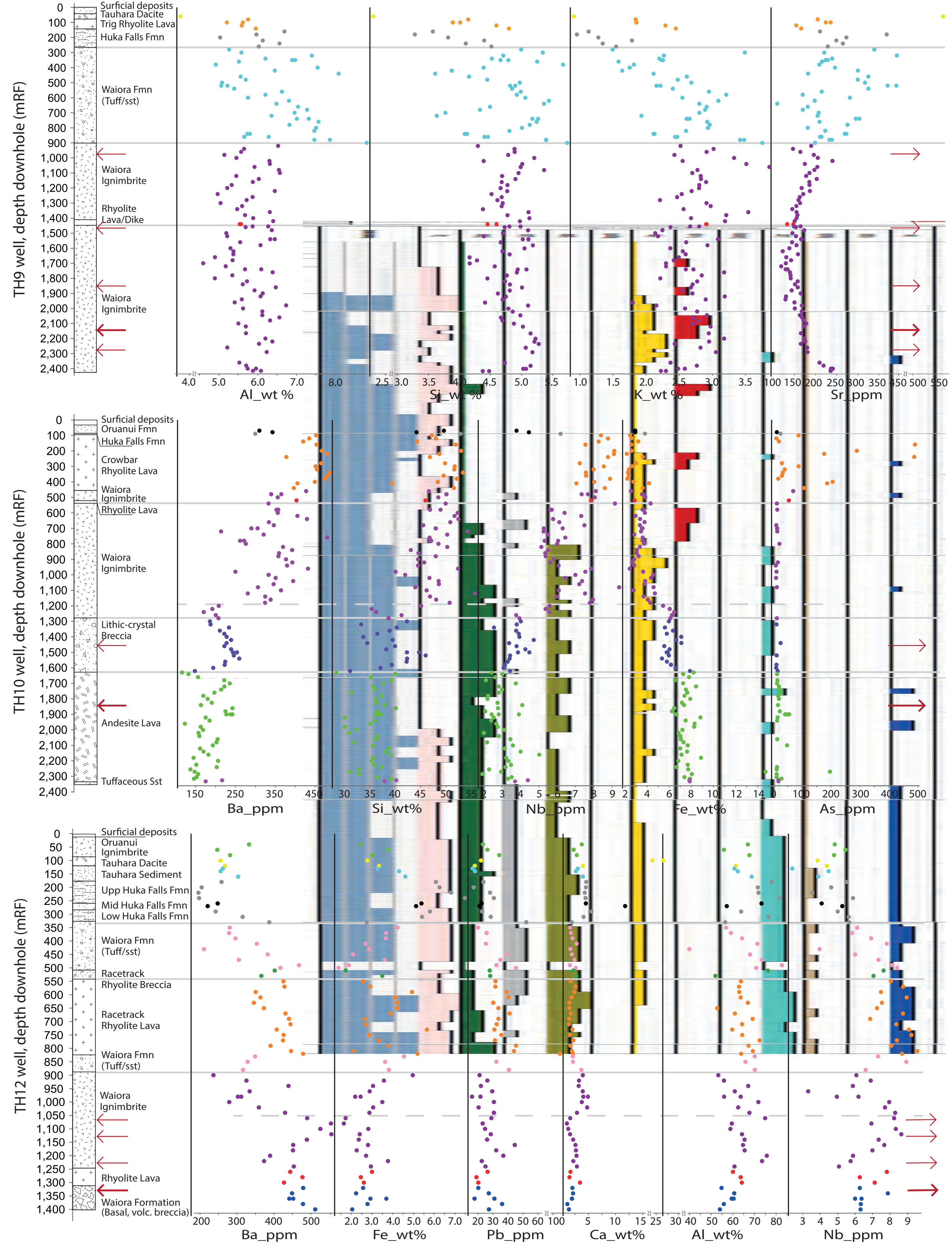

